\title{
Integrating writing into the optics curriculum
}

\section{Grover Swartzlander, Maliaca Oxnam, Lisa Lebduska}

Grover A. Swartzlander Jr., Maliaca Oxnam, Lisa Lebduska, "Integrating writing into the optics curriculum," Proc. SPIE 9663, Eighth International Topical Meeting on Education and Training in Optics and Photonics, 96631Q (6 October 2003); doi: 10.1117/12.2207505

SPIE Event: Eighth International Topical Meeting on Education and Training in Optics and Photonics, 2003, Tucson, Arizona, United States 


\title{
Integrating Writing into the Optics Curriculum \\ Grover A. Swartzlander, Jr. ${ }^{1}$, Maliaca Oxnam ${ }^{\frac{2}{2}}$, and Lisa Lebduska ${ }^{3}$ \\ ${ }^{2}$ Optical Sciences Center, University of Arizona, Tucson, AZ 85719 \\ (520)626-3723 (voice), (520)621-3389 (fax), grovers@optics.arizona.edu \\ ${ }^{2}$ Science and Engineering Library, University of Arizona, Tucson, AZ 85719 \\ (520)621-6386 (voice), oxnamm@u.library.arizona.edu \\ ${ }^{3}$ Director of College Writing, Wheaton College, Norton, MA 02766 \\ (508)286-5429 (voice), llebdusk@wheatoncollege.edu
}

\begin{abstract}
In response to a need for interactive learning, we designed a physical optics course that incorporates writing-to-learn principles and allows students to meld in-class theory with real-world practice. Students "published" their papers on the open-access web. This exercise necessitated that students understand principles sufficiently to simplify complex topics for a broad general audience.
\end{abstract}

Advanced courses in physical optics require problem-solving skills that may include calculus, complex numbers, trigonometry, algebra, and graphical representations. Abstract concepts are described -- sometimes to explain commonly experienced phenomena. Rather than supplementing empirical knowledge, students often supplant it with an analytical version of nature. In large part this abandonment can be attributed to the lack of qualitative information covered in these courses. Academic institutions expect the syllabus to be densely packed with technical topics, leaving little class time for integrating analytical and qualitative knowledge. Many believe students would be better prepared to master their discipline if they had experience assimilating both types of information [1,2].

Given limitations of the syllabus and the schedule, a natural solution is to find sufficiently interesting projects for the students to explore qualitative aspects on their own. We have found that this goal can be achieved while also satisfying other missing elements such as writing, information and technical literacy, communication, and teamwork. A solution is to assign a writing project that describes to an educated audience either a physical phenomenon or to report on the life and science of a noteworthy scientist or engineer [3]. The students not only use the World Wide Web for researching their topic, thus gaining an exposure to information literacy, but they also publish their report as a web page, thus providing a very real and wide audience. This latter requirement gives the students a greater stake and sense of ownership in the project. Teamwork skills are honed as well, owing to the students' limited technical knowledge of searching and writing for the web.

This course, called "OPTI 310 - Physical Optics I" is taught in the fall semester at the University of Arizona Optical Sciences Center. The nominal student population is 30 mostly junior-year students majoring in an ABETaccredited Optical Sciences and Engineering program. The syllabus lists such topics as wave theory, reflection and refraction, polarization, interference, Fourier analysis, and Fraunhoffer diffraction. There are roughly 41 lecture periods and 4 in-class exams and one pre-test on the first day of class. Two or three computer-based computational type projects are assigned during the semester. The most significant writing project is a term paper, which is the subject of this communication.

The writing assignment requires each student to select as a topic an optical phenomenon. The primary objective is for the student to communicate the nature of this phenomenon in terms of physical optics principles to an advanced high school or college freshman. The desired report length is an equivalent of two or three pages of typed doublespaced text, discounting figures, equations, and references. A typed hard-copy report, however, is not allowed. 
Rather, the students must publish their report on the world-wide web, thereby allowing anyone to access the document. Milestones are set during the semester and one or two class periods are devoted to library search methods and elements of writing. Feedback from the professor is provided after completing each milestone.

Roughly half the students have no experience developing a web page. To gain this knowledge students must consult their peers or other information resources. Typically students team up with their OPTI 310 classmates to reach an adequate level of competency in this area. This sink-or-swim approach therefore encourages and rewards teamwork. There are a surprising number of ways a student can approach web writing; for example, free sites that sport pop-up advertisements, software packages (Netscape Composer, Dreamweaver, Front Page, Bbedit, etc.), and html translators in software products such as Microsoft Word and Powerpoint. In retrospect we found it necessary to limit which approaches to allow. We also found it advantageous to restrict the report to a single web page with no links to subsequent pages.

Students reported in anonymous course evaluations that they appreciated an opportunity to develop a more complete understanding of a topic and to exercise communication skills that demonstrated to the world their level of mastery. We believe that the act of writing, with its challenges in the art of decision-making, gave students practice in the "uncertainty" that is a universal component of "all engineering design" [4]. As writers, the students had to exercise judgment and make decisions in a context very different from the dichotomous right or wrong arena of problem solving. Finally, the idea that science was again living, that it spoke a language beyond mathematics helped stoke the exhausted flames of scientific passion at the mid-point of the students' undergraduate experience.

We note that science faculty are sometimes reluctant to teach with writing for several reasons. Some fear that they need specialized knowledge in grammar or the teaching of composition; others fear that bringing writing into the science classroom will detract from the time devoted to content. However we believe faculty are often frustrated when they teach material that is soon forgotten (e.g., the meaning and use of equations, technical definitions, or proper approaches to particular problems). We were determined to provide an assignment with a lasting impact, and something that the students could share with their parents or friends (and indeed the world). Through writing, each student had the opportunity to develop an integrated understanding of a topic, thus enhancing the ability to recall the material at a later date. Furthermore the act of publishing the work instills a sense of pride and ownership, and a tendency to do well and show it off. Our experiences confirmed what Bean points out in Engaging Ideas [5], namely, that because we were teaching with writing, the writing became a tool with which we could actively engage students. Furthermore, because each student's web pages was available to the other students, they all gained experience forming a knowledge community. Learning was allowed to become dynamic and student-based and less reliant on a single authority figure.

In addition to the many benefits of integrating writing into a course curriculum, it is important to note that more than just individuals benefit from this type of course assignment. In 2000 ABET revised its accreditation standards to focus on demonstrated student learning rather than course offerings and statistics. A course that integrates writing requirements, such as OPTI 310, helps to demonstrate how students meet several of the learning outcomes set forth under ABET Criterion 3, XXX. The Learning Outcomes are listed in Table. I. Besides contributing toward the successful demonstration of the ABET Criterion, the course assignment also helps to meet the Information Literacy Competency Standards adopted in January 2000 by the American Association for Higher Education (AAHE) and the 
Association of College \& Research Libraries (ACRL). In today's society of information overload, the standards, listed in Table II, are aimed toward the development of information-smart, life-long learners.

TABLE I

ABET CRITERION 3 LEARNING OUTCOMES

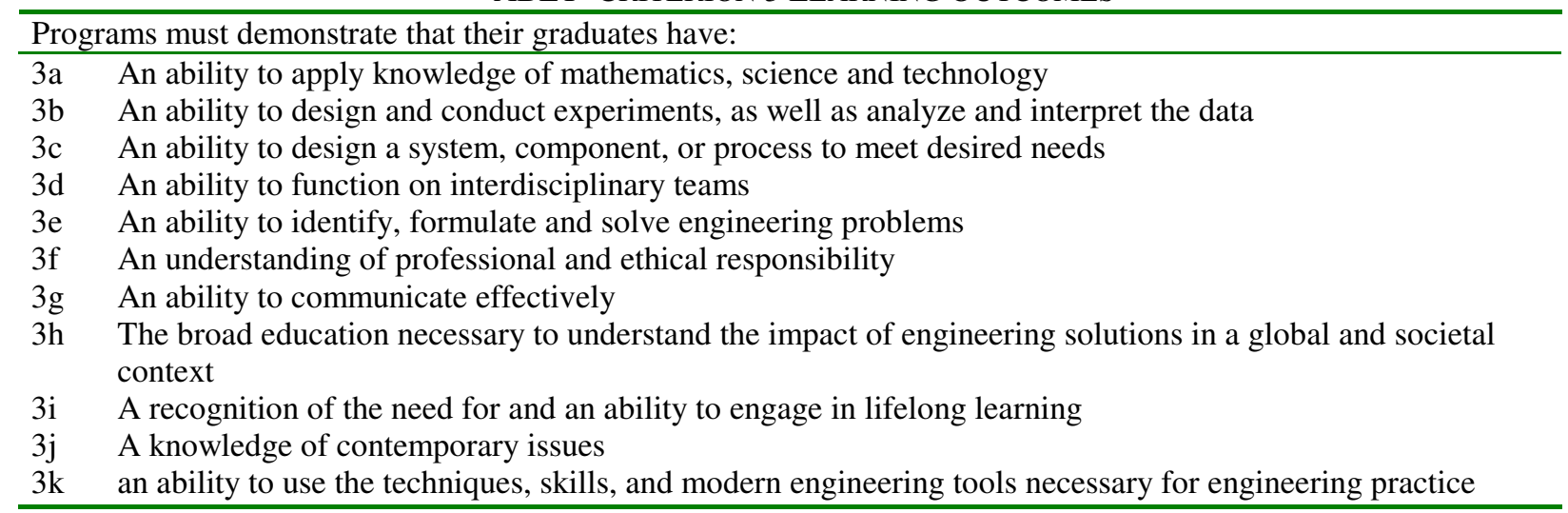

\section{TABLE II}

ACRL INFORMATION LITERACY COMPETENCY STANDARDS FOR HIGHER EDUCATION

\footnotetext{
Standard 1

The information literate student determines the nature and extent of information needed.

Standard 2

The information literate student accesses needed information effectively and efficiently.

Standard 3

The information literate student evaluates information and its sources critically and incorporates selected information into his or her knowledge base and value system.

\section{Standard 4}

The information literate student, individually or as a member of a group, uses information effectively to accomplish a specific purpose.

\section{Standard 5}

The information literate student understands many of the economic, legal and social issues surrounding the use of information and accesses and uses information ethically and legally.
}

\section{References and Acknowledgements}

This work was supported by the State of Arizona..

1. Kranber, M. "Educating the Whole Engineer." ASEE Prism. (November 1993): 28.

2. Engineering Accreditation Commission, "Criteria for Accrediting Engineering Programs (Effective for Evaluations During the 2003-2004 Accreditation Cycle)", Posted online: http://www.abet.org. (02/04/2003).

3. G. A. Swartzlander, Jr. and L. Lebduska, "Interactive Freshman Electromagnetism," ASEE/IEEE Frontiers in Education Conference Proceedings, Paper 1313, IEEE Catalog No. 02CH37351C, ISBN: 0-7803-7445-2.

4. Hazelrigg, G. A. "Rethinking the Curriculum.” ASEE Prism, (December 1994): 56.

5. Bean, J. Engaging Ideas: The Professor's Guide to Integrating Writing, Critical Thinking, and Active Learning in the Classroom. San Francisco: Jossey-Bass, 1996 